\title{
The Outcomes of the Co-branding Strategy
}

\author{
Magdalena Grebosz \\ Lodz University of Technology, Lodz, Poland
}

\begin{abstract}
The objective of this study is to investigate the outcomes of co-branding strategy in the assessment of the brand managers of analysed companies on European market and verification if a co-branding gives the opportunities for internal and external development. The analysis of correlation between the outcomes of co-branding and two major categories of co-branding strategy (ingredient branding and symbolic co-branding) are also important. In the paper the results of empirical studies are presented. Recent primary research (2009-2011) was conducted in 50 companies which are present in minimum three countries of Europe and have realized co-branding strategy for three years. Questionnaire surveys were carried out throughout all 120 identified companies. As a result, data from 50 companies were obtained, which amounted to $41.7 \%$ of all companies polled. The analysis of findings indicates the different outcomes in case of two major categories of co-branding strategy. The results show the general evaluation of the co-branded projects as well as the possibilities of the internal and external development. The results also emphasize the significance of symbolic character of the co-branding strategy. The recommendations in this study are set forth, of course, with the caveat as to the limitations of the sample. Nonetheless, it is believed that the results of this study will alert companies to the potential outcomes of co-branding taking into account the category of cooperation. This research has resulted in practical contribution. From the substantive stand point, this research has shed light on the outcomes of co-branding. This information can be useful for managers to understand which effects can be expected. From a theoretical and practical standpoint, this research contributes to brand alliances research and has provided a better understanding of outcomes of co-branding and the correlations between the possibilities of internal and external development and chosen category of co-branding strategy. This text may contribute to further research in this area and as a kind of motivator for further discussion on this topic.
\end{abstract}

Keywords: co-branding, partner, brand, cooperation, alliance, strategy

\section{Introduction}

The strong competition between manufacturers and retailers in saturated markets, shortened product lifecycles and the customer's sophistication push the companies to research the possibilities of the brands development. From this perspective, cooperation can be a source of competitive advantage of different enterprises regardless of industry, size or degree of innovation. As well as seeking ways to extend the brand through new product development, companies should look at opportunities to exploit the equity in their brands through co-branding, licensing, and franchising (Clifton, 2003). Consequently co-branding has become a popular

\footnotetext{
Magdalena Grebosz, Ph.D., Assistant Professor, Faculty of Organization and Management, Lodz University of Technology. Correspondence concerning this article should be addressed to Magdalena Grebosz, ul. Wolczanska 215, 90-924 Lodz, Poland. E-mail: magdalena.grebosz@p.lodz.pl.
} 
strategy employed by many of leading companies and can be a good way of exploiting a brand, broadening its exposure and enhancing its message. The decision about co-branding is based on the assessment of strategic and operational opportunities of this cooperation as well as on the analysis of potential risks related particularly with the dilution of the brand equity.

\section{Conceptual Background}

Many definitions of co-branding exist at organisational, promotional, product and ingredient level. Keller, Apéria, and Georgson (2008) stated that co-branding occurred when two or more brands were combined into a joint product or were marketed together in some fashion. According to Helmig, Huber, and Leeflang (2008), co-branding represented "a long-term brand alliance strategy in which one product is branded and identified simultaneously by two brands". Park, Jun, and Shocker (1996) defined co-branding as the pairing of two or more branded products (constituent brands) to form a separate and unique product (composite brand) and Blackett and Boad (1999) viewed co-branding as the mutual enhancement of two brands through close association of a product or service. Most Authors agree that co-branding involves combining two partners' brands to create a single product or offering. Taking into consideration these definitions, in the paper the co-branding is defined as the strategy of double branding of products when two distinct partners brand names are used in one product even if a composite brand is created. Simultaneously the partner's brands should be independent before and after co-branding project and this cooperation should be visible for potential customers. According to this definition, co-branding is distinguished from other alliances and other forms of cooperation, like co-advertising and co-promotion (joint promotion).

The different classifications of co-branding are considered in literature. In this paper the classification of Michel (2004) is applied. She distinguished functional co-branding (ingredient branding) and symbolic co-branding (co-naming). Ingredient branding consists in indicating the brand of one or more components of the end product. Such a form of cooperation between two companies is aimed at underlining the high quality of the product and the manufacturers' competence. Symbolic co-branding—co-naming—consists in the application of another brand in order to stress some symbolic values and create an image.

In the case of co-branding, we can also distinguish two partners' brands: an inviting or accepting brand, and a brand invited for cooperation. Co-branding may have an open or exclusive character. In the case of open co-branding, the brand, which is invited for cooperation, is also often cooperating with other competitive brands. Co-branding based on exclusivity obliges cooperating brands to limit their cooperation only to one brand (Grebosz, 2008).

Co-branding is an extremely potent tool for development of market and industry. It is capable of bringing new customers to products, refreshing brand image, increasing the market share or developing the technologies in companies through technical knowledge exchange. Co-branding is also a method to minimize costs. The co-branding should help to reduce risk connected with the brand extension. Successful co-branding occurs when partner's brands add value to a partnership. Co-branding should increase the level of partner's brands equity. With an existing cause, co-branding is a mean for companies to complement their existing brand image with specific associations that are "borrowed" or "transferred" from a cause (Kotler \& Keller, 2006). According to the signalling theory (Wernerfelt, 1988; Erdem \& Swait, 1998), the combination of two brands provides greater 
assurance of product quality than does a single branded product. Consequently co-branding should also lead to higher product evaluations and premium prices (Rao, Qu, \& Rueckert, 1999). Essentially the motivation for co-branding is founded on internal and external development opportunities.

Co-branding also has limitations. Such relationships usually involve complex legal contracts and licenses. Co-branding partners must carefully coordinate their marketing activities and take care of own and partner's brands to protect the final brand image (Kotler \& Amstrong, 2009). Co-branding may negatively influence the brand equity and in effect limit market reach or even discourage existing customers.

\section{Hypotheses}

In recent years, the author observes the concentration of the researcher's efforts on the analysis concerning the influence of co-branding on the customers behaviours and attitudes. The effects that co-branding have on consumers have been researched extensively inter alia by Rao and Ruekert (1994), Park et al. (1996), A. Levin, Davis, and I. Levin (1996), Simonin and Ruth (1998), Rao et al. (1999), McCarthy and Norris (1999), Vaidyanathan and Aggarwal (2000), Desai and Keller (2002) or Washburn, Till, and Priluck (2004). However, the analysis of the outcomes of co-branding strategy evaluated by the companies is also interesting and these effects—-from point of view of the firms should be studied.

In this paper, two following research questions are identified: Which are the outcomes of the realization of co-branding strategy? If the effects of ingredient branding are the same that in case of symbolic co-branding? And if co-branding is founded on internal or external development opportunities? Thus, the following hypotheses are set forth:

H1: Co-branding strategy gives the opportunity of the market development.

H2: Co-branding strategy helps to the brand development.

\section{Research Design}

\section{Research Framework}

The objective of this study is to investigate if a co-branding strategy gives the opportunities for internal (brand) and external (market) development on the basis of evaluation of the outcomes of co-branding by the brand managers of studied companies on European market (see Table 1). The analysis of correlation between the outcomes of co-branding and two major categories of co-branding strategy (ingredient branding and symbolic co-branding) is also important.

Table 1

Research Characteristics

\begin{tabular}{|l|l|}
\hline Scope & Description \\
\hline Issues & Co-branding strategy-outcomes and co-branding project management \\
\hline Characteristics of the companies & $\begin{array}{l}\text { 50 large international companies operating in Europe engaged in co-branding projects, which } \\
\text { are present in minimum three countries of Europe (including France, Italy, Finland, Germany, } \\
\text { Spain, Poland, Netherlands, Switzerland) and have realized co-branding strategy for three } \\
\text { years }\end{array}$ \\
\hline Period of research & $2009-2011$ \\
\hline Geographical scope & Europe \\
\hline Research method & Personal survey, electronic survey and paper survey \\
\hline
\end{tabular}




\section{Research Method}

The final research was conducted in 2010-2011 between the brand managers with the application of the techniques of personal survey, electronic survey and paper survey. The statistical and Windows Excel, computer software programs were used to collect data and make the analysis. The choice of companies to be studied was a deliberate one. The sample was not representative. A full list of companies was prepared in the first half of 2009. On its basis, 120 companies operating in Europe engaged in co-branding projects were identified. Questionnaire surveys were carried out throughout all identified companies. As a result, data from 50 companies were obtained, which amounted to $41.7 \%$ of all the companies polled. The studied companies represent different sectors and various kinds of activity, 35 of the studied companies operate on B2C and six companies on B2B market, nine companies operate in both sectors. Among the companies surveyed, 40 companies deal in manufacturing, six companies deal in trade and four companies provide services. The surveyed companies are characterized by a varied structure of employment and belong to various sectors. Among the studied companies, several companies represent each of the following: food, automobile, pharmaceutical, cosmetic as well as retail chains and the banking sector. Some of the studied companies also belong to the telecommunication, energy, textile, insurance, furniture, and electronic sectors. The diversity of types of activity, the size of the companies, as well as sector segments in which they operate enable one to carry out an in-depth analysis of the co-branding strategy.

Thirty nine of the companies studied apply ingredient branding strategy and 11 applied the strategy of symbolic co-branding, 30 companies represent inviting brand and 20 of them invited brand. All the companies declared that they had previous experience in the implementation of co-branding strategy.

\section{Results Analysis}

The analysis of the results of survey helps to determine the major outcomes of co-branding and checks the hypotheses concerning the opportunities of the internal and external development. The brand managers have evaluated the indicated factors (see Table 2) using the six point scaled from 0 to 5 (where 0 -means lack of effect, 5-very important effect). The hypotheses are analysed on the base of the evaluation of the outcomes (5) and (9)—H1 and the outcomes (1), (2), and (3)—H2.

Table 2

The Potential Co-branding Outcomes

\begin{tabular}{|l|}
\hline Outcomes \\
\hline (1) use of knowledge and experience of partner's brands in brand management area \\
\hline (2) refreshment of the brand image \\
\hline (3) reinforcement of the brand equity \\
\hline (5) entry on the new markets segments \\
\hline (9) entry on the new foreign markets \\
\hline
\end{tabular}

Among the most important outcomes of the co-branding strategy, the brand managers mentioned the use of knowledge and experience of partner's in brand management area (average 4.02), refreshment of the brand image (average 3.76) and the reinforcement of the brand equity (average 3.58). As we can note three major's effects of the realisation of co-branding strategy have symbolic character and are connected especially with intangible features of brand. 


\section{Hypotheses Testing and Discussion}

The results of research show the high evaluation of brand image and brand equity refreshment and reinforcement (see Table 3). They emphasize the significance of the possibilities of the brand associations' transfer and growth of the brand awareness thanks to realization of co-branding strategy. The high evaluation of the three first outcomes - use of knowledge and experience of partner's brands in brand management area, refreshment of the brand image and reinforcement of the brand equity—confirms the hypothesis $\mathrm{H} 2$.

The companies evaluate better the possibility of entry on the new markets segments (average 3.04) that entry into the new foreign markets (average 2.14) through the realization of co-branding strategy. It is inter alia the consequence of occasional cooperation between brands from different countries. In the most of cases, this type of cooperation is limited to the co-branding between foreign brands from portfolios of one international company. However the averages on the level 2.14 (for entry into the new markets segments) and 3.04 (entry into the new foreign markets) forced to partially reject the hypothesis $\mathrm{H} 1$.

To check the hypotheses, also the correlations among the different categories of co-branding and the evaluation of outcomes were calculated. The analysis of results shows that the correlations between outcomes and category of co-branding are on the high level (see Table 3).

Table 3

Assessment of Chosen Outcomes According to Category of Co-branding

\begin{tabular}{llll}
\hline Outcome & $\begin{array}{l}\text { General } \\
\text { assessment }\end{array}$ & $\begin{array}{l}\text { Assessment by companies which } \\
\text { applied ingredient branding } \\
\text { strategy }\end{array}$ & $\begin{array}{l}\text { Assessment by companies which } \\
\text { applied symbolic co-branding } \\
\text { strategy }\end{array}$ \\
\hline $\begin{array}{l}\text { (1) use of knowledge and experience of } \\
\text { partner's brands in brand management area }\end{array}$ & 4.02 & 3.90 & 4.45 \\
(2) refreshment of the brand image & 3.76 & 3.56 & 4.45 \\
(3) reinforcement of the brand equity & 3.58 & 3.41 & 4.18 \\
(5) entry on the new markets segments & 3.04 & 2.85 & 3.73 \\
(9) entry on the new foreign markets & 2.14 & 1.79 & 3.36 \\
\hline
\end{tabular}

The companies which have realized the strategy of ingredient branding confirmed that the co-branding allows use of knowledge and experience of partner's brands in brand management area, refresh the brand image and reinforce the brand equity (see Table 3). These findings confirm the hypothesis $\mathrm{H} 2$ in case of realisation of ingredient branding strategy. The companies which applied functional co-branding strategy gave low grade for the entry into the new market segments as well as the new foreign markets (see Table 3). Consequently the hypothesis $\mathrm{H} 1$ is rejected in case of ingredient branding strategy.

The companies which were engaged in the realization of symbolic co-branding stressed especially the possibility of use of knowledge and experience of partner's brands in brand management area, refreshment of the brand image and reinforcement of the brand equity (see Table 3). They evaluated higher-than the companies which applied ingredient branding strategy - the possibility of the entry on the new market segments as well as on the new foreign markets (see Table 3). These findings confirm the hypotheses $\mathrm{H} 1$ and $\mathrm{H} 2$ in case of symbolic co-branding.

The results confirm that different categories of co-branding should be analyzed taking into account different variables. The results from empirical study illustrate that co-branding gives the opportunity of the brand 
development in case of both categories of this strategy and helps to the market development in case of realisation of symbolic co-branding strategy.

\section{Research Limitations and Implications}

Although this research has provided initial findings concerning to co-branding outcomes, there is a certain number of limitations and it is important to delimit the contributions of this research properly. The recommendations in this study are set forth, of course, with the caveat as to the limitations of the sample (only 50 companies were investigated, however they represented $41.7 \%$ of all the companies polled). Nonetheless, it is believed that the results of this study will alert companies on the potential outcomes of co-branding taking into account the category of cooperation. However, to provide a more comprehensive picture of the outcomes of co-branding, similar studies could be done for different product categories.

This research has a certain number of theoretical and managerial implications. First, from a theoretical perspective, it provides a clearer understanding of the outcomes of co-branding projects and their influence on the possibilities of internal and external development. Second, from a managerial perspective, this research provides marketing managers with practical diagnostic of the co-branding outcomes. The results presented in this paper support managers in the decision concerning realization of the co-branding strategy.

Due to the relatively large topics and themes unrecognized, the author hopes that the presented text may contribute both to further research in this area, as well as a kind of motivator for further discussion on this topic.

\section{Conclusions}

In today's marketplace, increasing competition, homogenization of consumers' tastes, increasingly uniform living standards in urbanized countries, technological revolution and development of communication cause the evolution of inter-brand cooperation in a variety of forms. Forming brand alliances with other firms has become a strategic tool used by many companies to attain internal and external development.

The primary objective of this research was to investigate if a co-branding strategy gives the opportunities for internal (brand) and external (market) development on the basis of evaluation of the outcomes of co-branding by the brand managers of studied companies on European market. The analysis of findings showed that the major outcomes of co-branding are the use of knowledge and experience of partner's brands in brand management area, the refreshment of the brand image and the reinforcement of the brand equity. These results as well as the analysis of the theoretical background and the results of previous research emphasizes the significance of the symbolic character of co-branding strategy even in case of the application of ingredient branding (functional co-branding) strategy and confirm the hypothesis H1, that co-branding strategy helps to the internal (brand) development. Through the outcomes of co-branding strategy, that help in the external (market) development we can distinguish the entry into the new markets segments and the entry into the new foreign markets. The findings suggest that the limited possibilities of the market development, especially in case of application of ingredient branding strategy.

In summary, the hypotheses testing provided support for $\mathrm{H} 2$ and partial support for $\mathrm{H} 1$ which was confirmed in case on symbolic co-branding and rejected in case of ingredient branding (functional co-branding).

In conclusion, this research has resulted in two important contributions. From a theoretical standpoint, this research contributes to brand alliances research and has provided a better understanding of possibilities of the 
market and brand development after the application of co-branding strategy and the correlations between these results and chosen category of co-branding. From the substantive stand point, it has shed light on the differences between the opportunities offered by co-branding for the companies choosing ingredient branding and symbolic co-branding strategy. This information can be useful for managers to understand which outcomes can be expected.

Actually the application of co-branding strategy, when two or more brands endorse each other in the marketplace, is an important strategy for the brands transition and development.

\section{References}

Blackett, T., \& Boad, B. (1999). Co-branding: The science of alliance. New York, N.Y.: St. Martin’s Press.

Clifton, R. (2003). The future of brand. In R. Clifton \& J. Simmons (Eds.), Brands and branding. London: The Economist.

Desai, K. K., \& Keller, K. L. (2002). The effects of ingredient branding on strategies on host brand extendibility. Journal of Marketing, 66(1), 73-93.

Erdem, T., \& Swait, J. (1998). Brand equity as a signalling phenomenon. Journal of Consumer Psychology, 7, 131-157.

Grebosz, M. (2008). Brand managemen. Lodz: The Technical University Press.

Helmig, B., Huber, J-A., \& Leeflang, P. S. H. (2008). Co-branding: The state of the art. Schmalenbach Business Review (SBR), 60(10), 359-377.

Keller, K. L., Apéria, T., \& Georgson, M. (2008). Strategic brand management: A European perspective. Harlow: Pearson Education.

Kotler, P., \& Armstrong, G. (2009). Marketing: An introduction. London: Pearson Prentice-Hall.

Kotler, P., \& Keller, K. L. (2006). Marketing management. New Jersey: Pearson International Edition.

Levin, A., Davis, J., \& Levin, I. (1996). Theoretical and empirical linkages between consumers' responses to different branding strategies. Advances in Consumer Research, 23, 296-300.

McCarthy, M. S., \& Norris, D. G. (1999). Improving competitive position using branded ingredients. Journal of Product and Brand Management, 8(4), 267-285.

Michel, G. (2004). Au coeur de la marque. Paris: Dunod.

Park, C. W., Jun, S. Y., \& Shocker, A. D. (1996). Composite branding alliances: An investigation of extension and feedback effects. Journal of Marketing Research, 33(11), 453-466.

Rao, A. R., \& Ruekert, R. W. (1994). Brand alliances as signals of product quality. Sloan Management Review, 36(1), 87-97.

Rao, A. R., Qu, L., \& Rueckert, R. W. (1999). Signalling unobservable product quality through a brand ally. Journal of Marketing Research, 36, 258-268.

Simonin, B. L., \& Ruth, J. A. (1998). Is a company known by the company it keeps? Assessing the spillover effects of brand alliances on consumer brand attitudes. Journal of Marketing Research, 35(1), 30-42.

Vaidyanathan, R., \& Aggarwal, P. (2000). Strategic brand alliances. Journal of Product and Brand Management, 9(4), $214-226$.

Washburn, J. H., Till, B. D., \& Priluck, R. (2004). Brand alliance and customer-based brand-equity effects. Psychology and Marketing, 21(7), 487-508.

Wernerfelt, B. (1988). Umbrella branding as a signal of new product quality: An example of signalling by posting a bond. RAND Journal of Economics, 19, 458-466. 